\title{
A simple method for detection of mutations in amino acid 452 of the Spike protein of SARS-CoV-2 using restriction enzyme analysis.
}

\author{
Rossana C. Jaspe ${ }^{1}$, Yoneira Sulbaran ${ }^{1}$, Mariana Hidalgo ${ }^{2}$, Carmen L. Loureiro ${ }^{1}$, \\ Zoila C. Moros ${ }^{3}$, Domingo J. Garwaro ${ }^{1}$, Héctor R. Rangel ${ }^{1}$ and Flor H. Pujol \\ ${ }^{1}$ Laboratorio de Virología Molecular, Centro de Microbiología y Biología Celular, \\ Instituto Venezolano de Investigaciones Científicas, Caracas, Venezuela. \\ ${ }^{2}$ Laboratorio de Inmunoparasitología, Centro de Microbiología y Biología Celular, \\ Instituto Venezolano de Investigaciones Científicas, Caracas, Venezuela. \\ ${ }^{3}$ Laboratorio de Biología de Virus, Centro de Microbiología y Biología Celular, \\ Instituto Venezolano de Investigaciones Científicas, Caracas, Venezuela.
}

Key words: COVID-19; SARS-CoV-2; Delta Variant of Concern; RFLP; rapid sereening; mutation L452R.

\begin{abstract}
Variants of Concern or Interest of SARS-CoV-2 (VOC or VOI), the coronavirus responsible for COVID-19, have emerged in several countries. Mutations in the amino acid 452 of the Spike protein are particularly important and associated with some of these variants: L452R, present in Delta VOC, and L452Q, present in Lambda VOI. These mutations have been associated with both increased infectivity and evasion of protective immune response. A search on GISAID to detect the number of sequences harboring the L452R mutation and the frequency of Delta VOC among them, showed that since August 2021, most of these sequences belong to the Delta VOC. Restriction enzyme analysis is proposed as a rapid method to detect L452R. A small amplicon from the Spike gene was digested with MspI. A 100\% concordance was observed between digestion and sequencing results. The mutation L452Q can also be detected by restriction analysis, allowing the identification of putative Lambda VOIs. The proposed methodology, which allows screening of a great number of samples, could provide a faster information on the prevalence of Delta VOC cases.
\end{abstract}

Corresponding author: Flor H Pujol. Laboratorio de Virología Molecular, Instituto Venezolano de Investigaciones Científicas, CMBC, Caracas ,Venezuela .Tel/Fax: +58-2125041623. E-mail: fhpujol@gmail.com 


\title{
Un método simple para la detección de mutaciones en el aminoácido 452 de la proteina de la Espiga del SARS-CoV-2, usando análisis de enzimas de restricción.
}

\author{
Invest Clin 2021; 62 (4): 371-377
}

Palabras clave: COVID-19; SARS-CoV-2; Delta Variant of Concern; RFLP; detección rápida; mutación $\mathrm{L} 452 \mathrm{R}$.

Resumen. Las variantes de preocupación o interés del SARS-CoV-2 (VOC o VOI, por sus siǵlas en inglés), el coronavirus responsable de la COVID-19, han surgido en varios países. Las mutaciones en el aminoácido 452 de la proteína de la Espiga son particularmente importantes y están asociadas con algunas de estas variantes: L452R, presente en la VOC Delta, y L452Q, presente en la VOI Lambda. Estas mutaciones se han asociado con un aumento de la infectividad y la evasión de respuesta inmunitaria protectora. Una búsqueda en GISAID para detectar el número de secuencias que alberǵan la mutación L452R y la frecuencia de la VOC Delta entre ellas, mostró que desde agosto de 2021, la mayoría de estas secuencias pertenecen a la VOC Delta. Se propone el análisis de enzimas de restricción como un método rápido para detectar L452R. Se digirió un pequeño amplicón de un fragmento del gen de la espiǵa con MspI. Se observó una concordancia del 100\% entre la identificación de la mutación a través de la digestión y los resultados de la secuenciación. La mutación L452Q también se puede detectar mediante análisis de restricción, lo que permite la identificación de posibles VOI Lambda. La metodología propuesta, que permite el cribado de un gran número de muestras, podría contribuir a proporcionar más información sobre la prevalencia y a detectar rápidamente los casos de la VOC Delta.

Received: 05-09-2021 Accepted: 26-10-2021

\section{INTRODUCTION}

The COVID-19 pandemic is eaused by an emerging coronavirus, SARS-CoV-2, and has caused more than 200 million cases and more than 4 million deaths worldwide. This virus belongs to the family Coronaviridae. The tremendous number of replication events that this virus has experienced, in addition to an elevated frequency of recombination, and the probable action of host deaminases on the viral genome (1), has allowed the emergence of many mutations in the viral genome (2).
Different variants (lineages of viruses sharing particular types of mutations) have emerged since the end of 2020. Some of these variants have been defined as of Interest (VOI) or Concern (VOC) by WHO, associated with more transmissibility, or partial resistance to protective immunity, among other characteristics. The variants with confirmed increased capacities are named VOC (3-7). There are at present four VOCs: variant Alpha which emerged in the UK, variant Beta in South Africa, variant Gamma in Brazil and variant Delta in India. Genomic surveillance is recommended for monitoring 
the introduction of SARS-CoV-2 Variants of Concern (VOCs) in each country $(6,7)$.

Multiple mutations have emerged at amino acid 452 of the Spike protein, particularly L452R and L452Q. L452R was first described in variants from California US at the end of 2020 (Epsilon Variant), and has now been found in several lineages (8), notably including Delta VOC (3). In the Fall of 2021, Delta VOC is predominating in many countries, despite high vaccination coverages (9-11). The Delta variant has been associated with higher viral load compared to previous SARS-CoV-2 isolates (12), being at least two-times more transmissible than the original isolate first detected in $\mathrm{Wu}$ han (13), and possibly associated with an increased severity (14). Delta VOC is now predominating in many countries and is thought to predominate in more countries with time.

Thus, rapid detection of Delta VOC cases can be particularly useful in a clinical setting or for epidemiological purposes. L452R, a characteristic mutation of Delta VOC, can be detected by partial or complete genome sequencing and also by real-time PCR with commercial probes. Here we propose an alternative method for rapid detection of this mutation by restriction enzyme analysis, which can also be applied to the L452Q allele, present in other variants like Lambda VOI (15).

\section{MATERIALS AND METHODS}

Sequences available at GISAID on September 25, 2021, were analyzed for the presence of L452R, at https://www.gisaid. org/phylodynamies/global/nextstrain/ and https://www.epicov.org/. The number of sequences belonging to the Delta VOC among the ones harboring this mutation was also estimated.

A restriction enzyme analysis was developed to detect the presence of L452R mutation. RNA from clinical samples positive by qRT-PCR (classified upon sequencing as wild-type, WT, or harboring L452R mutation) was amplified with primers $76.1 \mathrm{~L}$ and $76.8 \mathrm{R}$ as previously described (16). Five $\mu \mathrm{L}$ of the amplicon were digested with 1 unit of MspI for 1 hour at $37^{\circ} \mathrm{C}$ and then loaded in a 3\% agarose gel electrophoresis for band visualization with Ethidium bromide. Restriction results were compared with the sequence obtained by sending PCR purified fragments to Macrogen Sequencing Service (Macrogen, Korea). This study was approved by the Bioethical Committee of IVIC.

\section{RESULTS}

All sequences available at GISAID on September 25, 2021 were analyzed for the presence of L452R. At GISAID a total of $1,269,918$ sequences of SARS-CoV-2 harboring the mutation L452R were available in samples collected between January 12021 and August 31 2021. Fig. 1 shows the frequency of Delta VOC sequences for each month. Since June 2021, 98\% of the sequences harboring the L452R mutation correspond to Delta VOC. Before this date, Delta VOC accounted only for $44 \%$ of the sequences harboring the mutation L452R, while $36 \%$ of them were grouped in lineages B.1.427 or B.1.429, known as Epsilon variant (8).

Fig. 2 shows the expected restriction pattern of Wild Type (WT) samples and isolates harboring mutations L452R or L452Q, by using two restriction enzymes: MspI for L452R and BsrI for L452Q: each enzyme yields an additional restriction site in the respective mutated sample. Fig. 2C shows the digestion of the PCR-amplified product with the MspI enzyme of two samples with the L452R mutation and two WT samples. A total of 56 samples were analyzed for their restriction pattern with MspI enzyme, and compared to the presence or not of the mutation L452R in their sequence. A 100\% concordance was observed in the detection of the L452R mutation between the two methods (Table I).

Vol. 62(4): 371 - 377, 2021 


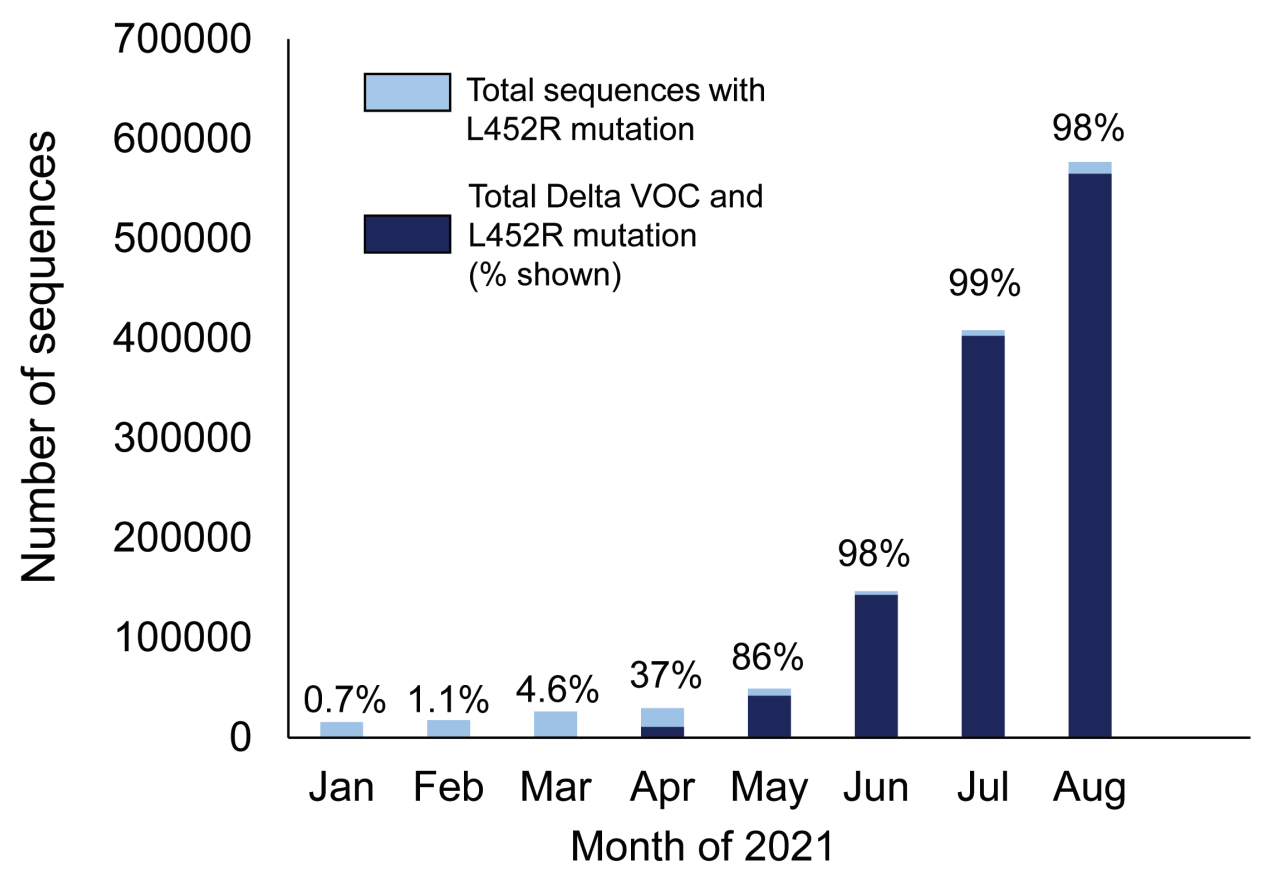

Fig. 1. Number of sequences with L452R mutation available at GISAID from January to August, aceording to the month of collection. The total number of sequences harboring the mutation L452R is shown for each month (bars). The number of these sequences belonging to lineages B.1.617.2 is shown in dark blue: the percent number is shown for each bar.

TABLE I

CONCORDANCE BETWEEN RESTRICTION

ENZYME ANALYSIS AND SEQUENCING

RESULTS.

\begin{tabular}{cccc}
\hline $\begin{array}{r}\text { Sequence analysis } \\
\text { Restriction analysis }\end{array}$ & R42 & R452 & \\
\hline L452 & 33 & 0 & \\
R452 & 0 & 23 & $100 \%$ \\
\hline
\end{tabular}

A total of 56 samples were analyzed: 23 Delta, with L452R, and 33 non-Delta, Variants Alpha, Gamma, and $\mathrm{Mu}$, and other lineages.

\section{DISCUSSION}

Delta VOC is becoming the predominant lineage of SARS-CoV-2 in many countries $(8,17)$. The presence of one of its most important mutation, L452R, does not necessarily mean the presence of a Delta VOC isolate, but, as shown in Fig. 1, this association is at present very high, because of the predominance of the Delta VOC in many countries. This mutation is not the only one responsible for the particularly high fitness phenotype of Delta VOC: P681R, for example, has been associated with a more fusogenic phenotype, conferring more pathogenicity to virus harboring this mutation in experimental animals $(9,18)$.

On the other hand, the presence of $\mathrm{L} 452 \mathrm{Q}$ does not mean either the identification of the Lambda VOI, but in regions where this variant circulates, it could be strongly correlated. Thus a rapid method for identifying those mutations should be very useful, particularly in settings where massive whole genome sequencing is not available. Rapid methodologies might be used for the rapid screening of several samples. The whole protocol can be run in a day.

The proposed methodology allows analyzing a great number of samples to select samples that may harbor mutations of concern, before proceeding to whole genome sequencing. It also allows analyzing samples with suspicion of Delta VOC in a short time, without the need for commercial kits, before getting sequencing results. On the oth- 


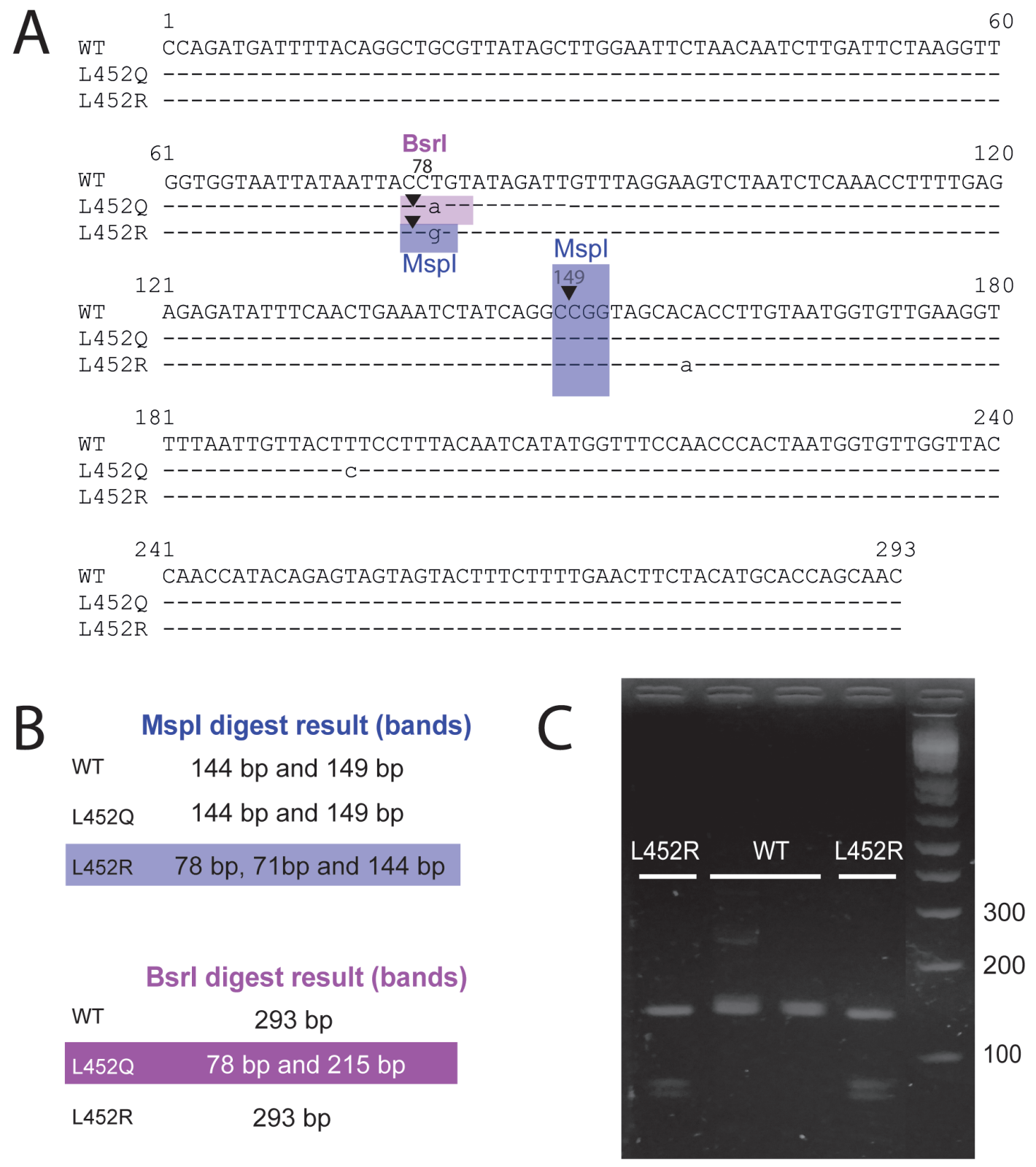

Fig. 2. Restriction analysis of amplicons with L452R or L452Q mutations. A. Sequence of the amplified product showing the restriction sites which discriminate Wild-type (WT) or mutant (L452R or L452Q) viruses. The use of these two enzymes generates a restriction pattern characteristic for each situation (WT, L452R and L452Q). The restriction sites are underlined. The numbers in the alignment indicate the bp position in the PCR-amplified product. Nucleotides 79-81 code for the amino acid L452 (CTG), R452 (CGG), or Q452 (CAG). B. Expected digestion pattern with MspI enzyme and similar enzymes (restriction site CCGG) and with BsrI and similar enzymes (restriction site ACTGG). With MspI digestion, WT amplicon generates a product with two close bands of 140-155, while L452R mutated amplicon generates 3 bands: two close bands of 71-78 and one of $144 \mathrm{bp}$. With BsrI digestion, WT amplicon generates an undigested product of $293 \mathrm{bp}$, while L452Q mutated amplicon generates two bands of 78 and $215 \mathrm{bp}$. C. Agarose gel electrophoresis of PCR-amplified products digested with MspI. The PCR-amplified products digested with the MspI enzyme were run with molecular weight markers (1Kb plus DNA ladder): smaller bands are signaled (100, 200, and $300 \mathrm{bp})$.

Vol. 62(4): 371 - 377, 2021 
er hand, once the presence of the variants is confirmed by whole genome sequencing, this method can be used for the rapid estimation of their prevalence in different geographical regions. We previously reported a restriction analysis to detect another important mutations: E484K or E484Q in the RBD of the Spike protein (16). This method was particularly useful during the dissemination of Gamma VOC in Venezuela (Jaspe, RC, personal communication). We have already experienced in our laboratory the usefulness of these restriction analysis, which can be also combined for detecting several VOCs.

\section{ACKNOWLEDGEMENTS}

This study was supported by Ministerio del Poder Popular de Ciencia, Tecnología e Innovación of Venezuela. We wish to thank Dr. Ferdinando Liprandi for his suggestion to performing this study and for critical reading of the manuscript.

\section{REFERENCES}

1. Pujol FH, Zambrano JL, Jaspe R, Loureiro CL, Vizzi E, Liprandi F, Rangel HR. Biología y evolución del coronavirus causante de la COVID-19. Rev Soc Venezol Microbiol 2020; 40:63-70.

2. Phan T. Genetic diversity and evolution of SARS-CoV-2. Infect Genet Evol 2020; 81:104260. Available from: https://doi. org/10.1016/j.meegid.2020.104260.

3. Rotondo JC, Martini F, Maritati M, Mazziotta C, Di Mauro G, Lanzillotti C, Barp N, Gallerani A, Tognon M, Contini C. SARS-CoV-2 infection: new molecular, phylogenetic, and pathogenetic insights. Efficacy of current vaccines and the potential risk of variants. Viruses 2021; 13:1687. https://doi.org/10.3390/v13091687.

4. World Health Organization. https://www. who.int/publications/m/item/weekly-epidemiological-update-on-covid-19---22-june-2021.

5. Noori M, Nejadghaderi SA, Arshi S, Carson-Chahhoud K, Ansarin K, Kolahi AA, Safir S. Potency of BNT162b2 and mRNA-
1273 vaceine-induced neutralizing antibodies against severe acute respiratory syndrome-CoV-2 variants of concern: A systematic review of in vitro studies. Rev Med Virol 2021;e2277. doi: 10.1002/rmv.2277.

6. Salleh MZ, Derrick JP, Deris ZZ. Structural evaluation of the spike glycoprotein variants on SARS-CoV-2 transmission and immune rvasion. Int J Mol Sei 2021; 22: 7425. doi: 10.3390/ijms22147425.

7. European Centre for Disease Prevention and Control. SARS-CoV-2 variants of concern as of 18 June 2021. https://www.eede. europa.eu/en/cases-2019-ncov-eueea

8. Tehesnokovaa V, Kulasekarae H, Larsona L, Bowersd V, Rechkinab E, Kisielaa D, Slednevab Y, Choudhury D, Maslovab I, Denge $\mathrm{K}$, Kutumbakac $\mathrm{K}$, Genge $\mathrm{H}$, Fowlere C, Greenee D, RalstoneJ, Samadpoure M, Sokurenkoa E. Acquisition of the L452R mutation in the ACE2-binding interface of Spike protein triggers recent massive expansion of SARS-CoV-2 variants. $\mathrm{J}$ Clin Microbiol 2021:JCM0092121. doi: 10.1128/JCM.00921-21..

9. del Rio C, Malani PN, Omer SB. Confronting the Delta Variant of SARS-CoV-2, Summer 2021. JAMA 2021: E1-E2.

10. Herlihy R, Bamberg W, Burakoff A, Alden N, Severson R, Bush E, Kawasaki B, Berger B, Austin E, Shea M, Gabrieloff E, Matzinger S, Burdorf A, Nichols J, Goode K, Cilwick A, Stacy C, Staples E, Stringer G. Rapid increase in circulation of the SARS-CoV-2 B.1.617.2 (Delta) variant-Mesa County, Colorado, April-June 2021. MMWR Morb Mortal Wkly Rep 2021;70:1084-7. https://doi. org/10.15585/mmwrmm7032e2

11. Mishra S, Mindermann S, Sharma $M$, Whittaker C, Mellan TA, Wilton T, Klapsa D, Mate R, Fritzsche M, Zambon M, Ahuja M, Howes A, Miscouridou X, Nason GP, Ratmann O, Semenova E, Leech G, Sandkühler JF, Rogers-Smith C, Vollmer M Unwin HJT, Gal Y, Chand M, Gandy A, Martin J, Volz E, Ferguson NM, Bhatt S, Brauner JS, Flaxman S, COVID-19 Genomics UK (COG-UK) Consortium. Changing composition of SARS-CoV-2 lineages and rise of Delta variant in England. EClinicalMedicine 2021;39:101064. doi: 10.1016/j. eclinm.2021.101064. 
12. Teyssou E, Delagrèverie $H$, Visseaux $B$, Lambert-Niclot S, Brichler S, Ferre V, Marot S, Jary A, Todesco E, Schnuriger A, Ghidaoui E, Abdi B, Akhavan S, Houhou-Fidouh N, Charpentier C, MorandJoubert L, Boutolleau D, Descamps D, Calvez V, Marcelin AG, Souliea C. The Delta SARS-CoV-2 variant has a higher viral load than the Beta and the historical variants in nasopharyngeal samples from newly diaǵnosed COVID-19 patients. J Infect 2021; 83:e1-e3. doi: 10.1016/ j.jinf.2021.08.027.

13. Liu Y, Rocklöv J. The reproductive number of the Delta variant of SARS-CoV-2 is far higher compared to the ancestral SARSCoV-2 virus. J Travel Med 2021;taab124. doi: $10.1093 / \mathrm{jtm} / \mathrm{taab} 124$.

14. Ong SWX, Chiew CJ, Ang LW, Mak T-M, Cui L, Toh MPHS, Lim YD, Lee PH, Lee TH, Chia PY, Maurer-Stroh S, Lin RTP, Leo Y-S, Lee VJ, Lye DC, Young BE. Clinical and virological features of SARS-CoV-2 variants of concern: a retrospective cohort study comparing B.1.1.7 (Alpha), B.1.315 (Beta), and B.1.617.2 (Delta). Clin Infect Dis 2021; ciab721. doi: 10.1093/cid/ ciab721.
15. Padilla-Rojas C, Jimenez-Vasquez V, Hurtado V, Mestanza O, Molina IS, Barcena L, Morales Ruiz S, Acedo S, Lizarraga W, Bailon H, Cáceres O, Galarza M, RojasSerrano N, Vargas-Herrera N, Lope-Pari P, Huayra J, Solari L. Genomic analysis reveals a rapid spread and predominance of lambda (C.37) SARS-COV-2 lineage in Peru despite circulation of variants of concern. J Med Virol 2021:10.1002/jmv.27261.

16. Jaspe RC, Sulbaran Y, Loureiro CL, D’Angelo P, Rodríguez L, Garzaro DJ, Rangel HR, Pujol FH. Importance of mutations in amino acid 484 of the Spike protein of SARS$\mathrm{CoV}-2$ : rapid detection by restriction enzyme analysis. Invest Clin 2021; 62(Suppl. 2): 3-17.

17. Wang $Y$, Chen R, Hu F, Lan Y, Yang Z, Zhan C, Shi J, Deng $X$, Jiang $M$, Zhong $S$, Liao B, Deng K, Tang J, Guo L, Jiang M, Fan Q, Li M, Liu J, Shi Y, Deng X, Xiao X, Kang M, Li Y, Guan W, Li Y, Li S, Li F, Zhong N, Tang $\mathbf{X}$. Transmission, viral kinetics and clinical characteristics of the emergent SARSCoV-2 Delta VOC in Guanǵzhou, China. EClinicalMedicine 2021;40:101129. doi: 10.1016/j.eclinm.2021.101129.

18. Takeda M. Proteolytic activation of SARSCoV-2 spike protein. Microbiol Immunol. 2021. doi: 10.1111/1348-0421.12945. 